\title{
Objects, Elements, and Affirmation of the Ethical
}

\author{
Matthew Z. Donnelly \\ Boston College, Chestnut Hill, USA \\ Email: mdonnel4@gmail.com
}

Received January 27 ${ }^{\text {th }}$ 2013; revised February $28^{\text {th }}$, 2013; accepted March $14^{\text {th }}, 2013$

\begin{abstract}
Copyright (C) 2013 Matthew Z. Donnelly. This is an open access article distributed under the Creative Commons Attribution License, which permits unrestricted use, distribution, and reproduction in any medium, provided the original work is properly cited.
\end{abstract}

\begin{abstract}
The purpose of this paper is to demonstrate that the theory of material objects often referred to as mereological nihilism supports a fine-grained and analytically coherent reading of Emmanuel Levinas's concept of "elements" as articulated by Levinas primarily in Totality and Infinity. This reading, in turn, allows for a second conclusion, namely the affirmation of the ethical as the possible ground of all other philosophy.
\end{abstract}

Keywords: Levinas; Mereology; Ethical Phenomenology; Objectivity

\section{Introduction}

The purpose of this paper is two-fold. I intend to demonstrate that the theory of material objects often referred to as mereological nihilism - the denial of the proper objectivity of most things colloquially thought of as objects (van Inwagen, 1990: pp. 72-73)—supports a fine-grained and analytically coherent reading of Emmanuel Levinas's concept of “elements" as articulated by Levinas primarily in Totality and Infinity. This reading, in turn, allows for a second conclusion, namely the affirmation of the ethical as the possible ground of all other philosophy. I begin with a description of some basic concepts of mereological nihilism, and include use of a limited number of Levinasian terms in order to foreshadow and demonstrate mereological nihilism's coherence with aspects of Levinas's philosophy. The second section is an explicit treatment of Levinas's philosophy of elements as read from the perspective of mereological nihilism. The first purpose-demonstrating coherence between qualified mereological nihilism and Levinas's philosophy of elements-will be apparent throughout the first two sections. The second purpose is achieved in the third section, which describes the result of integrating mereological nihilism with Levinas's philosophy of elements, namely that the first objective relationships are those between individual people. This result, coupled with qualified acceptance of Levinas's broader philosophy, affirms the possibility of treating the ethical as the ground of philosophy.

A note on terminology: throughout this paper, I intend the terms proper object(s) to mean anything that meets the practical and conceptual requirements of material objectivity, and gross objects(s) to mean any object that can be considered a whole object composed of parts. Both proper and gross objects are also intended to be objects that are not merely arbitrarily construed, gerrymandered, or contrived through linguistic or conceptual manipulation. An example of such construed objects would be an object taken as the set of 1) the Horsehead Nebula, 2) former German chancellor Helmut Kohl, and 3) the Stanley Cup. Clearly such a set is not a proper object, yet some set- theories of material objectivity might allow for it to be treated as if it were. I intend to avoid such gerrymandering. Included in the class of proper gross objects are, among many possibilities, people, animals, and plants. The term simple object(s) is intended to mean any elemental or fundamental particle, things that are unitary whole objects but are not composed of constituent parts. In all other cases, the terms thing and object should be understood loosely, colloquially, and with an agnostic attitude as to whether they indicate something that should rightly be called a proper object. When possible, I will use the term pseudo-object to indicate a thing with merely the appearance of proper objectivity. Additionally, this paper begins with the condition that the proper objectivity of all candidates for objectivity in doubt.

\section{Objects}

Peter van Inwagen's theory of material objects ${ }^{1}$ is the result of investigations into the topic of parts and wholes. Specifically, it is a response to the question "In what circumstances is a thing a (proper) part of something?” (van Inwagen, 1990: p. 20). An alternate, and perhaps more manageable formulation of this question $^{2}$, is to ask under what conditions "a plurality (or aggregate, array, group, collection, or multiplicity) of objects” can be counted as a whole thing (van Inwagen, 1990: p. 22). For the purposes of investigating a human's relationship with Levinas's elements, one must ask: Under what conditions do (Levinas's) elements become a proper object that can be enjoyed?

Van Inwagen restates his central question as "Less formally, in what circumstances do things add up to or compose something? When does unity arise out of plurality?” (van Inwagen,

\footnotetext{
${ }^{1}$ Van Inwagen's theory of material objects is by no means universally accepted. Kathrin Koslicki, for example, presents a viable, neo-Aristotelian alternative to van Inwagen's theory (Koslicki, 2008). Amie Thomasson presents a theory of "ordinary objects" in opposition to mereological nihilism (Thomasson, 2007). If one objects to van Inwagen's theory, but wishes to retain this paper's central theses, a major rearticulation of this paper's demonstration will be necessary.

${ }^{2}$ Referred to as the Special Composition Question.
} 


\section{Z. DONNELLY}

1990: p. 31) The most intuitive answer to this question, especially with an eye towards enjoyable objects derived from elements, is that parts, or lesser objects, in contact over time become a proper object. This is the same four-dimensional theory described by W. V. O. Quine in Philosophy of Logic (Quine 1970: p. 30). For example, logs arranged to provide shelter ${ }^{3}$ in a certain manner are not commonly understood as instances of elements arranged in a certain way, but are rather understood, referred to, and enjoyed as shelter. Contact, however, fails to provide sufficient ground for such gross objectification. Van Inwagen uses the example of two people shaking hands to demonstrate that the world is full of things in contact with one another over time that are not gross objects (van Inwagen, 1990: p. 36). People shaking hands and holding hands have the same relation, namely contact over time, as logs stacked to form shelter or logs fallen upon one another in a forest. “...the mere fact that they come into contact cannot be a complete explanation of the generation of a new thing that is their sum" (van Inwagen, 1990: p. 37).

Exclusivity - that one thing is not a part of more than one gross object-or what van Inwagen refers to as "uniqueness" (van Inwagen, 1990: p. 42) does not make contact sufficient for explaining gross objectivity. For example, a tomato may be in contact with the rest of the potential object referred to as my salad, and this salad is the tomato's only salad, however, a AAA battery might drop into my salad bowl and enter into the same contact and exclusive relationship with my salad as the tomato. For the sake of my stomach lining, I hope none would say that the AAA battery is a proper part of my enjoyable salad.

Contact and exclusivity are the two most apparent candidates for answers to questions of composition. Other possible answers, such as fusion and cohesion, fail to provide necessary and sufficient ground for the composition of gross objects for the same reason that contact does (van Inwagen, 1990: p. 70) Take, for example, the battery and salad. If the battery leaked fluids, and through some quirk of chemistry fused with or stuck to the salad, or if it was ripped open and its jagged edges fastened onto my salad, I would still hesitate to say that the AAA battery composed a proper part of the salad which I am about to enjoy.

Though van Inwagen's theory of material objects is far more detailed than presented here, the preceding paragraphs should give one a clear idea of what (supposed) things are not proper objects, and why. The salad, sandals, and houses that a person enjoys are not themselves proper gross objects because they only achieve objectivity through refuted criteria such as contact, fastening, or fusion. They are instances of smaller (potential) things arranged, fastened, put into contact, fused, and otherwise manipulated for teleological purpose. Similarly, accidents of history create other things often thought of as proper objects. A mountain, for example, is merely a heap of rock, sand, and dirt arranged by the unintentional hand of geology. A great many of the things that a person enjoys and lives from, though handled and thought of as proper objects, are not proper gross objects. If this is the case, are people and the Levinasian notion of the face of the Other proper objects, or are we all merely accidents of history and physical process, however beautiful, ugly, or ethically relevant we may be?

Perhaps such failures of objectivity are merely failures of appropriate definitions. It is possible that we need to enrich our

\footnotetext{
${ }^{3}$ Otherwise known as a "building” or "house".
}

understanding of the mundane notion of objectivity; however, we should be careful not to enrich the definition to the point of totality. If objectivity is understood as any group of "things," whatever they may be, taken as an object then any grouping, however silly, may be taken as counting as a proper object. If the pillows in a child's pillow fort may be granted objectivity as the object "pillow-fort," so too may the set named "fliberdigibit" which consists of my computer, the politician Al Gore, and a particular coffee bean in Kenya. I grant that such linguistic gymnastics are possible; however I strongly hesitate to say that they are either useful or interesting. When all things may be grouped together in any arbitrary fashion, objectivity itself becomes arbitrary. This is a conclusion we ought to avoid.

It is also clear that the results of van Inwagen's investigation do not deny the existence of objects altogether. It is uncontroversial to assert that various fundamental particles such as quarks, bosons, electrons etc. ${ }^{4}$ are objects. These are unquestionably proper objects because they are without troublesome parts (van Inwagen, 1990: p. 165), and are empirically ${ }^{5}$ identifiable. Furthermore, fundamental particles-simples-are necessary for any theory of material objects that contains at least some gross objects (van Inwagen, 1990: pp. 98-99). These fundamental particles are arranged by the processes of history and the hands of man to form the things colloquially referred to as objects.

Other things may indeed qualify as proper objects despite the pessimism in the conclusion of the investigation into composition. Though contact and other, similar grounds of objective composition are insufficient, other promising principles of composition remain unexamined. The most apparent is that principles of composition will involve or include causation (van Inwagen, 1990: p. 81). Causation, by itself, is also intuitively insufficient, as the previously discussed principles of contact and fusion demonstrate. Merely because lettuce, tomatoes, and a AAA battery are causally combined, intentionally or naturally, in contact or fusion ${ }^{6}$ does not make a salad a gross proper object. A specific kind of causal relationship is needed to allow for proper coherent gross objectivity.

Aside from fundamental particles, the most intuitively proper object is a particular human life. A human life, like a salad or log shelter, is composed according to specific causality. Unlike a mountain or heap of logs, however, a human life, in most cases, causes and maintains its own existence as an object. Returning to the question of composition, van Inwagen articulates this kind of composition by stating that for every object $y$, "xs compose y" "if and only if... the activity of the xs constitutes a life (or there is only one of the xs)" (van Inwagen, 1990: pp. 82, 91). The gross objectivity of a (human) life depends on the activity of the xs that compose the life. The implications of this principle seem incredible. There is a significant difference, primarily in size, between fundamental particles (cases where there is only one " $x$ ") and a fully formed human being. In other words, for this principle to hold, a set of non-arbitrarily defined fundamental particles must actively exist together and thereby

\footnotetext{
${ }^{4}$ If these prove to be divisible into parts, then they will not themselves be simple objects, and the newly discovered particles will supplant them as fundamental particles and therefore as the class of simple objects. It is for particle physicists to describe the most fundamental particles and therefore the class of simple objects.

${ }^{5}$ Or theoretically empirically identifiable, in the case of certain fundamental particles.

${ }^{6}$ Or another, similar, candidate for objective composition.
} 


\section{Z. DONNELLY}

constitute a whole object qua life. Intuitively, one wants to say that the parts of a human being are arms, legs, hair, skin etc. and not quarks, gluons, electrons etc. yet an eyelash is merely a collection of fundamental particles in cohesive contact over time. Fundamental particles, it seems, are the only proper parts of a human being qua proper gross object.

In addition to activity, the constitution of a life ${ }^{7}$ must be stable (van Inwagen, 1990: p. 84). For initial discussion, let us count only what cannot be denied as a "life". Boundary cases, such as a fertilized egg cell or a human body without brainwave function, can be set aside for the time being. Similarly, the definition of "life" is by no means rigid, and descriptively follows from the things (lives) it applies to. Put differently, living things existed before the notion of "alive" was articulated. The requirement of stability over time is the driving force behind the need for the enjoyable aspects of elements. A living object, such as a human being, in the world is "needy" (Hirst, 2007). By digestion, respiration, and other manner of "jealous" selfpreservation, a (human) life maintains its constitution (van Inwagen, 1990: p. 121). Additionally, this stable, active constitution must be both individuated - it cannot be a proper part of another gross object-and it must also be self-directed. (van Inwagen, 1990: p. 87) Self direction and the accompanying conscious intentionality - for human lives, at least-are what give rise to the enjoyment of living from the elements. This intentionality grounds sensible objectification (Drabinski, 2001: p. 83) and pseudo-objectification, and therefore apperception of the elemental (Drabinski, 2001: p. 110). Additionally, as van Inwagen articulates, "The nature of the physical universe is such that the mere existence of a living organism, the mere fact that it is distinguishable from its environment, means that it is in a state of jeopardy" (van Inwagen, 1990: p. 92). Yet "the element suits me-I enjoy it” (Levinas, Totality and Infinity, 1969: p. 141). Where there are no active operations to maintain a certain constitution, there is no life (van Inwagen, 1990: p. 157) and therefore no gross object.

Though Levinas rightly resists describing the human body as something that should be treated as a thing (Levinas, Totality and Infinity, 1969: p. 229), his concept of thing most likely falls closer to the colloquial concept of object than it does to any other expressible concept. If the previous description of proper gross objectivity coheres with the mundane notion of proper gross objectivity, it does not, therefore, necessarily conflict with the current concept of a human life as a proper object. In denying the thingness of the human body, Levinas affirms the importance of the human body acting "for itself." As previously discussed, the activity of being for itself is precisely what defines a human life as a proper gross object. In other words, human life is homeodynamic and constitutes and conducts itself in order to perpetuate is own continued existence as an object. It constitutes and conducts itself, at least in most circumstances, to remain alive. The human being is active in ways that pseudo-objects are not, and has a complex constitution in ways that simples do not. The presented description of a human life qua proper object is not pernicious to Levinas's concept of the

\footnotetext{
${ }^{7}$ For initial discussion, let us count only what cannot be denied as a "life." Boundary cases, such as a fertilized egg cell or a human body without brainwave function, can be set aside for the time being. Similarly, the definition of "life" is by no means rigid. Rather, it is the mundane, everyday notion of life - the same characteristic we understand to be shared by dogs, cats, humans, and ferns, to name four examples. Put differently, living things existed before the notion of "alive" was articulated.
}

human body.

A human life's being for itself is manifested in activity, both internal-metabolism, for instance-and external-labor. A stack of logs arranged into shelter is the product of two levels of arrangement. The first level of arrangement is of various fundamental particles arranged log-wise by the process of a tree's life ${ }^{8}$ and various other natural processes. The second level of arrangement is by human activity (van Inwagen, 1990: p. 127), arranging logs shelter-wise for the purpose of human enjoyment. It is through this second level of arrangement and manipulation of fundamental particles that lives, most notably human lives, live in the world. By heaping numbers of fundamental particles conveniently arranged by physical and natural processes into enjoyable (potential) objects, and subsequently enjoying them, humans are able to maintain themselves as "homeodynamic storms of simples" (van Inwagen, 1990: p. 121) This heaping and arranging is, to use more Levinasian terms, "labor," and it is the activity by which human beings maintain themselves as proper objects in a threatening, almost "absurd" world (Lingis, 2010: p. 71).

\section{Elements}

Elements, or the elemental, are described as a component of Levinas's analysis of human beings' relations with things. According to Levinas, human beings live from enjoyment ${ }^{9}$ of elements. Enjoyment is the proper relationship to things (Sallis, 2010: p. 91), or as the previous section described, the proper relation to pseudo-objects. We breathe air, walk on earth, eat food, drink water, and create shelter. The environment of the world "nourishes" and “supports" us (Lingis, 2010: pp. 67-68). Levinas does not give a taxonomically extensive treatment of elements in Totality and Infinity ${ }^{10}$, but he does describe elements in ways similar to the modern understanding of fundamental particles. Of the sea and wind as used by a ship's navigator, Levinas writes that "They retain the indetermination ${ }^{11}$ of elements despite the precision of the laws that govern them, which can be known and taught. The element has not forms containing it; it is content without form" (Levinas, Totality and Infinity, 1969: p. 131). Fundamental particles and compilations of fundamental particles - elements - arranged $^{12}$ sea and windwise can also be described in this manner. A gust of wind or ocean current, though treated as an object, is not a proper object. The laws governing fundamental particles and the pseudo-objects they compose are, more or less, known or knowable, yet their compilation and potential objectivity remains indeterminate because they are not properly objectified.

When one enjoys potential objects derived from elements, one enjoys elements in the guise of gross objects, even though such gross objects are merely pseudo-objects. Levinas expresses the necessary relationship between a person and elements by writing "The relation adequate to its essence discovers it precisely as a medium: one is steeped in it; I am always

\footnotetext{
${ }^{8}$ Though the tree may be properly called a gross object, once the tree is chopped down and is dead, it cannot be called a life. Therefore its status as a proper object is in doubt.

${ }^{9}$ That enjoyment is the only relationhip between human beings and elements is perhaps a contentious proposition. (Sallis, 2010: p. 94).

${ }^{10}$ As Alphonso Lingis aptly observes, Levinas provides a similar description of materiality in Existence and Existents, albeit in different language. (Lingis, 2010: p. 76).

${ }^{11}$ Emphasis added.

${ }^{12}$ By some process, human or natural.
} 


\section{Z. DONNELLY}

within the element" (Levinas, Totality and Infinity, 1969: p. 131). Out of this medium, the human beings draw or take enjoyable pseudo-objects, viewed, referred to, and understood as if they were proper objects. One would be similarly correct in stating that human beings are always within a mélange of fundamental particles and from the fundamental particles draws practical pseudo-objects. Van Inwagen concedes the necessary practical aspect of pseudo-objectification to language and concepts; however, he does not grant that it leads to a "common sense" understanding of objects. Rather, he denies that there are such objects as "chairs" and "tables" (van Inwagen, 1990: pp. 102-104), and therefore denies the premises of the "common-sense" view of objectivity. Language would be unnecessarily cumbersome if one had to express such concepts as "salad" with the phrase "a collection of fundamental particles arranged salad-wise.” Just imagine what a waste of paper and ink $^{13}$ a household shopping list would be! Salads, shelter, and breaths of air are the kinds of pseudo-objects one enjoys and lives from. Yet these pseudo- objects are not, as demonstrated, proper objects. Elements are not best understood ${ }^{14}$ as the set of worldly objects that include food, shelter, and other pseudoobjects that human beings enjoy. Indeed, one should not limit the concept of the elements to a local set of objects ready-tohand for human enjoyment. There are not, for example, stacks or warehouses - conceptual or physical-of breaths from which human beings live. Rather there are virtually innumerable molecules of oxygen, carbon-dioxide, and the like from which a human being, in enjoying air, makes the type of pseudo-objects named breaths.

Similarly, there are not shelters, or even logs from which one can build shelter, but rather numbers of fundamental particles arranged log-wise. From initial arrangements of fundamental particles, human beings gather and rearrange the elements into pseudo-objects. From primary, natural arrangements of elements, human being rearrange the stuff of the world into object-like collections of elements. In order for human beings to enjoy elements, they must (re)arrange the elements into object-like collections. It is impossible to enjoy the elemental as elemental rather than as objects, and it is impossible to enjoy a collection of fundamental particles rather than pseudo-objects. Human beings build or arrange something enjoyable out of the "frontier" of the "nothingness which separates" (Levinas, Totality and Infinity, 1969: p. 142). The nothingness Levinas describes is not pure nothingness, the general opposite of being as such, but rather a nothingness, and indefinable lack of proper objectivity. Levinas's "nothingness" could also be described as that which remains when all things are hypothetically destroyed or negated. (Sallis, 2010: p. 89) The material may not be annihilated, but as potential-and-pseudo-objects, such things are destroyed. As described, the elemental is indefinable, though regular and predictable. This indefinability is precisely the frontier out of which human beings must create ${ }^{15}$ enjoyability. Such creation is the active maintenance of the human life. It is the homeodynamism of the human storm of simples.

Labor-active maintenance of a life's constitution-is able to "ward off the threat" of a dangerous world (Levinas, Totality and Infinity, 1969: p. 166). Human lives, at least, are conscious, on multiple conceptual levels, of their finitude, and are aware of

\footnotetext{
${ }^{13}$ Or rather, a waste of fundamental particles arranged paper-and-ink-wise.

${ }^{14}$ Although it might be most practical to understand them as objects rather than collections drawn from the elemental.

${ }^{15}$ “Create” could also be understood as "pseudo-objectify".
}

their existence towards death (Heidegger, 1962). Sparing oneself from death, even if temporarily, leads to the experience of conscious satisfaction and enjoyment. Although this experience does not necessarily relieve a life of the existential angst described by Heidegger, even temporary relief from particular danger, mortal or otherwise, is undoubtedly satisfying. This experience of satisfying relief is relative and conditioned by circumstance, and so conditioned, will remain limited to its circumstance. Directing oneself toward a consciously experienced need derived from requirements of a stable constitution in a threatening world, and satisfying that need, are the material bases for enjoyment.

If one views a human life as a "homeodynamic storm of simples," the relationship between fundamental particles, simple objects themselves, and the gross object of a human being is clear. Modern biology has clearly demonstrated how human life is dependent upon molecular and atomic-level interactions. Atoms and molecules, certainly, are not proper objects. Though not proper objects, atoms and molecules-arrangements of simple objects-are the mediating mereological strata between simple objects and the human being qua gross object. Additionally, there is no necessary proper objective intermediary between fundamental particles and (human) lives. One might object that individual cells are necessary proper objects. In the case of single-celled organisms, this is true. However, in the case of gross objects like human beings, there are atoms and molecules - themselves collections of fundamental particlessuch as blood plasma, that are not cells but are necessary for the maintenance of life. The biological processes that move cells and other collections of fundamental particles about are necessarily vague, or as Levinas describes such concepts, "ambiguous” (Levinas, Totality and Infinity, 1969: p. 166) and the line between an independent, whole, and unified life and collections of simples at the cellular level might be difficult to define, if only because the relationship between parts and whole gross objects is vague ${ }^{16}$ (van Inwagen, 1990: pp. 154, 217). Even if an independent life as part of another life could be identified, it would violate the mereological principle of exclusivity-the "smaller" life would itself be both a part and a whole. Accepting such a theory of material objects clearly leads to the intractable problem of a simultaneous great and small number of objects in the world. Put another way, there would be both one all-encompassing proper object known as the world, and also innumerable other, smaller objects.

Despite the lack of proper objectivity in the pseudo-objects enjoyed by human beings, an intuitive incredulity remains. Though my salad may not be a proper object, I nonetheless enjoy it as if it were an object. Levinas writes that “... objective knowledge ... is marked by the way the knowing being has approached the real" (Levinas, Totality and Infinity, 1969: p. 64) Elements are real. Therefore, in order for "the knowing being" to approach and live from elements, there must be a measure, or sense, of objectification, despite a lack of objectivity. Pseudoobjectivity is granted by the knowing being's pragmatic orientation.

There is apparently an impasse between the lack of proper objectivity in the things enjoyed by human beings and the sense of objectivity that human beings necessarily experience when

\footnotetext{
${ }^{16}$ Similarly, the existence of an object qua life is itself vague. (van Inwagen, 1990: p. 241) The contentious contemporary debates about when a human life begins are evidence of this difficulty.

${ }^{17}$ Pseudo-objectification.
} 


\section{Z. DONNELLY}

living from elements. The escape from this impasse lies in the difference between a sense of objectification ${ }^{17}$ and proper objectification. I treat a salad as an object, though in even mundane, colloquial terms the salad is really a collection of objects-pieces of lettuce, tomato, carrot etc. My sense of "salad objectification" does not match the actual objectivity of the salad. The same could be said of elemental objectification. I may enjoy my shelter as if it was a gross object, yet in moments of mereological clarity I realize that it is not a proper object.

In the case of pseudo-objects enjoyed by human beings, full objectivity is never achieved. Yet the closer an object comes to being enjoyed by a person, the more it seems and is treated as an object. Lettuce in a field and logs in the forest become revealed to a human being as something with the character of “handiness" (Heidegger, 1962: pp. 62-67). Through spatial human discovery of things, things as spatially grounded are revealed. (Heidegger, 1962: p. 97). In Levinas’s words, “In this primordial grasp matter at the same time announces its anonymity and renounces it. It announces it, for labor, the hold on matter, is not a vision or thought in which matter already determined would be defined by relation to infinity; within the grasp matter precisely remains fundamentally indefinite and, in the intellectual sense of the term, incomprehensible” (Levinas, Totality and Infinity, 1969: p. 159) The pre-objective collection of fundamental particles "remain at the disposal of the $\mathrm{I}-$ to take or leave. Labor will henceforth draw things ${ }^{18}$ from the elements and thus discover the world. This primordial grasp, this enterprise of labor, which arouses things and transforms nature...” (Levinas, Totality and Infinity, 1969: p. 157). These things, of course, are merely pseudo-objects, objectified as spatial (res extensia) pseudo-objects in the same way that they are discovered to be in space, namely through human transcendence and active engagement. Original spatiality is given by an encounter with the Other (Levinas, Transcendence and Height, 1996: p. 17). In the case of elements, this active worldly and spatial engagement is rooted in the conceptual and material movement towards enjoyment. In order to enjoy a compilation of simple objects, one actively and materially pseudo-objectifies the compilation, perhaps, as Levinas would have it, derived from an original spatiality grounded in an encounter with the Other.

Yet in the moment that a pseudo-object is enjoyed, its sense of objectivity dissipates. In the moment that a breath of air is breathed-the molecules ${ }^{19}$ integrating with the human homeodynamic storm of simples - the breath of air ceases to be a breath qua pseudo-object. The same is true of eating and digesting salad. In the case of pseudo-objects whose constituent fundamental particles never merge with the human being, such as shelter, the dissipation of apparent objectivity is more difficult to describe. When such objects are enjoyed by a human being, they lose potential self-identical objectivity. The potential for objectification is "historical." As historical, it is "already passed by" (Levinas, Totality and Infinity, 1969: p. 65). Even if criteria such as contact held, upon enjoyment by a person, such objects as shelters become necessarily and qualitatively related to the person(s). When I enter a log shelter, the shelter becomes my shelter. The shelter is essentially my shelter, and is no longer a pseudo-object. The potential for objectivity is passed over as history, replaced instead by its reference to the

\footnotetext{
${ }^{18}$ Psuedo-objects.

${ }^{19}$ And their constituent fundamental particles (simple objects).
}

knowing being that enjoys the shelter. It “...thus refers to the project and labor of the knower...” (Levinas, Totality and Infinity, 1969: p. 65). It is my pseudo-object, an extension of my being in the world. Labor is a fundamental relation between human being and the elemental (Levinas, Totality and Infinity. 1969: p. 131). John Locke puts these principles succinctly when describing "my" human activity_-"labour" as that which has "fixed my property in" things of nature (Locke, 1690: p. 20). Levinas similarly places labor at the fore when dealing with understanding objectivity. (Levinas, Totality and Infinity, 1969: p. 65). Labor, he writes, fixes "the element" against its "uncertain future" ${ }^{20}$ in possession (Levinas, Totality and Infinity, 1969: p. 158). Though externally enjoyed pseudo-objects ${ }^{21}$ cannot be called proper parts of anything, let alone of a human being, because they are qualitatively and essentially related to a person through relations derived from labor and qualitative knowledge, they are more closely a part of the human than they are a part or pseudo-part of anything else.

For pseudo-objects that merge with a person and those that remain external, independent pseudo-objectivity dissipates upon enjoyment. The pseudo-objectivity of enjoyable elements is evanescent. There is a conceptual asymptote. Pseudo-objects approach objectivity, but never achieve proper and independent objectivity because they are either enjoyed and, in a conditionally particular way, incorporated into the gross objectivity of a person, or are cast aside and relegated to the status of pre-objective collection of fundamental particles. Pseudo-objects are either enjoyed or are dispersed into elements. This asymptote is also the point at which particular instances of parthood and objectivity become vague, although not troublingly so. The line between elements, or fundamental particles, as parts, and a whole gross object is vague (van Inwagen, 1990: p. 228). The point at which a fundamental particle that was once arranged salad or breath-wise, becomes a part of my body is vaguely definable at best. Is it in the mucus membranes in my mouth and throat? In my stomach or intestines? In my lungs? And in such processes, where is the threshold between myself and the world? By their very function, the membranes that allow me to enjoy salads or breaths of air are porous and able to integrate, to some extent, myself with the world external to myself. Similarly, at what point do collections of fundamental particles arranged shelter-wise become my shelter? When I build the shelter? When I enter the shelter the first time? When I decorate the interior? Despite vagueness at the material border between the elemental and a human being, an essential relationship of pseudo-objectification and the material and conceptual movement from element to person exists between human beings and elements.

Perhaps, Levinas's ethical phenomenology is incompatible with the fundamentally scientific or mundane perspective which holds fundamental particles as proper objects. While speculation on Levinas's opinion of the mereological status of bosons is futile, it also seems that his phenomenological writings offer clues that hint at a potential compatibility with a materialistic, scientific perspective typified by van Inwagen. Levinas agrees with both the mundane and mereological description of a human being as a proper object, writing of the Other that "He is a being (étant) and counts as such" (Levinas, Is Ontology Fundamental? 1996). This should come as no sur-

\footnotetext{
${ }^{20}$ And indefinability.

${ }^{21}$ Objects that do not merge with a human homeodynamic storm of simples.
} 
prise, for if anything at all is an object, as "being”s, certainly individual humans should be counted as such. Certainly there is no unaided phenomenological objectification of fundamental particles, but similarly, there is no fundamentally unaided phenomenological objectification of quasi-objects such as bottles and shoes. Whereas the objectification or similar understanding of fundamental particles is aided by scientific and theoretical constructs, such constructs are themselves the result of worldly objectification grounded in undeniable proper objects, namely other human beings. Bottles and shoes are similarly, in a Levinasian context, grounded in the encounter with the Other. The difference between a shoe and a boson is the level of mediation by gross proper objects (other humans) and gross quasi-objects (particle accelerators). The relationship between Levinas's phenomenology and modern science is the subject of a much longer treatise. For now, let it suffice that there is at least a nod to coherence.

\section{Affirmation of the Ethical}

Other human beings are proper gross objects. Levinas: "What presents itself as independent of every subjective movement is the interlocutor, whose way consists in starting from himself, foreign and yet presenting himself to me.” (Levinas, Totality and Infinity, 1969: p. 67) A human being (a human object) is "...presented when we have welcomed an interlocutor" (Levinas, Totality and Infinity, 1969: p. 69). The independence presented by the Other, in addition to his presenting himself as an active, jealous, self-maintaining constitution of materialflesh, surface, movement, and ultimately simple parts-confirms the proper objectivity of the Other. Levinas writes "The primordial sphere, which corresponds to what we call the same, turns to the absolutely other only on call from the Other. Revelation constitutes a veritable inversion objectifying cognition" (Levinas, Totality and Infinity, 1969: p. 67). The Other is the initial "transcendent, unthematizable," encounter (Richardson, 1995: p. 129). As such, the encounter with the Other is the initial encounter with transcendent, unthematizable, and proper object, and more broadly, the initial encounter with proper gross objectivity.

The relationship with the Other, and all of its ethical implications, is therefore the primordial relationship between a subject and any gross object, and the relationship between the subject and gross objectivity in general. As Levinas writes, "To recognize the Other is therefore to come to him across the world of possessed things ${ }^{22}$, but at the same time establish, by gift, community and universality" (Levinas, Totality and Infinity, 1969: p. 76). The Other, as proper object, grounds objectifying cognition in possession, community, and universality (Sealey, 2010: p. 366). Indeed, possession by the Other is prior to consciousness of that which is possessed (Tallion, 1995: p. 116). Without the Other, there are no possessions, no community, and no universality, including the universal sense of objectivity necessary to conceptually, linguistically, and practically handle compilations of simples. Indeed, Levinas describes an encounter with the Other as revealing a certain "...silent language, an understanding without words...” (Levinas, Totality and Infinity,

\footnotetext{
${ }^{22}$ For Levinas's purposes, these "things" do not need to be proper objects. Psuedo-objects, and their corresponding sense of objectivity, without proper objectivity, can be possesed by others.

${ }^{23}$ After translation from Levinas's phenomenological language into mundane and scientific language.
}

1969: p. 155).

One could easily take the notion of "universal being," (Levinas, Is Ontology Fundamental? 1996: p. 7) as the sum of all things, all of which can be described as fundamental particles ${ }^{23}$ If one wishes to articulate the extremely abstract notion of universal being, one quickly comes to a loss for words, for in language and articulation in general there is a separation, delineation. To attempt express such a notion, whether as the slippery notion of the sum of all that there is, or as universal being, language fails. The ground of particularity, of proper objectivity and the corresponding function of language $e^{24}$, must therefore come with the encounter of the Other. Levinas writes that "...the structure of the world resembles the order of language...” (Levinas, Meaning and Sense, 1996: p. 38). The language/world correspondence needs articulate objectification for its structure. Regarding the Other Levinas writes, "I have spoken to him, that is to say, I have neglected the universal being he incarnates in order to remain with the particular being he is" (Levinas, Is Ontology Fundamental? 1996: p. 7). The incarnation of the Other is, in other words, a function of objectivity. The Other is not a pseudo-object, but rather being in an unconquerable particular form. Negating the Other (as object) is total negation of comprehension, (Levinas, Is Ontology Fundamental? 1996: p. 9), comprehension that is surely grounded in some form of objectivity. If the preceding analysis is correct, one neglects the unobjectifiable, the elements, in order to ground ones incarnate objectivity in encounter with the Other. Without the Other, there is no proper objectivity, and no ground for a linguistic or objective world.

If one takes the foundation of metaphysics to be principles of objectivity and objective relationships, and takes these relationships to be expressible or cognizable in understanding and language (Martin, Metaphysical Foundations: Mereology and Metalogic, 1988: pp. 43, 341), the relationship between human objects, or perhaps all living objects (Calarco, 2010), is the foundation of metaphysics. Put another way, it is an understanding of enjoyment of the elements that allows one to move towards what various commentators have expressed as a reading of human being in the world as transcendent and ethically constituted (Westphal, 1995: pp. 67-71).

Because living objects ${ }^{25}$ have inherent ethical value, and if one takes metaphysics to be a holistic study of all "entities" (Martin, Logical Semiotics and Mereology, 1992: p. 198) the ethical is the ground of metaphysics, and indeed all other disciplines. Understanding of the world, as handled through logical objectification (and pseudo-objectification) begins with the understanding of objects as such. The first understanding of a plurality of objects is the value-laden ${ }^{26}$, and therefore ethical, relationship between living objects. All other forms of objectivity are derived from primitive ethical objective relationships. If one treats the world as the sum of all objects, pseudo-objects, and other things treated as objects, one might therefore affirm a version of primitive ethics as the most fundamental human relationship with and within the world. Though Levinas does not treat the world as merely "the sum total of objects within

\footnotetext{
${ }^{24}$ If one takes language to correspond, at least on some level to objectivitya potentially difficult, albeit intuitive notion of language.

${ }^{25}$ Whether the operative lives must be limited to human lives in order to be treated as the ground of ethics is a topic for another paper and other authors. ${ }^{26}$ I take it as self-evident that lives, at least human lives, are inherently valuable objects. If this is read as a contentious premise, I leave it to other authors to defend the inherent value of (human) life.
} 


\section{Z. DONNELLY}

it," he does affirm that "the world is what it is, a totality, because there is "someone"” in the world (Wyschogrod, 2000: p. 24). The "someone" is the Other. Some hold that Levinas "fails to come to terms with the ethical significance of the world" (Eubanks \& Gauthier, 2011). This reading reverses Levinas's priority. For Levinas, the ethical is prior to the possibility of world. The world does not have inherent ethical significance without the Other. The world is constituted ethically; one encounters ethically relevant objects-the Other-prior to curiously reckoning with the material world as material. The encounter with the Other is prior to the encounter with pseudoobjects such as tables, and is certainly prior to the heavily mediated apprehension of fundamental particles. One exists ethically prior to existing scientifically. The ethical constitution of one's world is based on the primordial encounter of the Other as proper and value-laden object. Indeed, the Other as separated object is the ground of subjectivity for Levinas (Nuyen, 2001: p. 436). The ontological constitution of the world is secondary to the ethical context of the encounter with the Other, in the condition of human beings together (Levinas, Is Ontology Fundamental? 1996: p. 3). For those who hold subjectivity or objective understanding to be the starting points for investigations into first philosophy, the affirmation of ethics as a candidate for first philosophy is undeniably powerful.

Affirmation of the ethical as a candidate for first philosophy is notable because it is born of a fundamentally metaphysical analysis, rather than an analysis begun with the same initial conditions as Levinas's philosophy. This, in turn, speaks to the power, importance, and scope of Levinas's thought, and that ethics' candidacy for first philosophy must be reckoned with by anyone wishing to seriously examine human being in the world.

\section{Acknowledgements}

Thanks to Adrienne Bogacz for initial proofreading and helpful comments and Damian Cleary for helpful comments.

\section{REFERENCES}

Calarco, M. (2010). Faced by animals. In P. Atterton, \& M. Calarco (Eds.), Radicalizing Levinas (pp. 113-135). Albany: State University of New York Press.

Drabinski, J. E. (2001). Sense and Singularity. Albany: State University of New York Press.

Eubanks, C. L., \& Gauthier, D. J. (2011). The politics of the homeless spirit: Heidegger and Levinas on Dwelling and Hospitality. History of Political Thought, 32, 125-146.
Heidegger, M. (1962). Being and time. Translated by John and Robinson, Edward Macquarrie. New York: Harper Collins,.

Hirst, A. (2007). Levinas separates the (hu)man from the nonhuman, using hunger, enjoyment and anxiety to illuminate their relationship. Cosmos and History: The Journal of Natural and Social Philosophy, 3, 159.

Koslicki, K. (2008). The structure of objects. Oxford: Oxford University Press. doi:10.1093/acprof:oso/9780199539895.001.0001

Levinas, E. (1996). Is ontology fundamental? In E. Levinas (Ed.), Basic philosophical writings (pp. 1-10). Bloomington: Indiana University Press.

Levinas, E. (1996). Meaning and sense. In E. Levinas (Ed.), Basic philosophical writings (pp. 33-64). Bloomington: Indiana University Press.

Levinas, E. (1969). Totality and infinity. Pittsburgh: Duquesne University Press.

Levinas, E. (1996). Transcendence and Height. In E. Levinas (Ed.), Basic philosophical writings (pp. 11-32). Bloomington: Indiana University Press.

Lingis, A. (2010). The environment: A critical appreciation of Levinas's analysis in existence and existens. Levinas Studies, 5, 65-82.

Locke, J. (1690). Second treatise of government. Cambridge: Hackett Publishing.

Martin, R. M. (1992). Logical semiotics and mereology. Amsterdam: John Benjamins Publishing Company.

Martin, R. M. (1988). Metaphysical foundations: Mereology and metalogic. Munich: Philosophia Verlag.

Nuyen, A. T. (2001). The "ethical anthropic principle" and the religious ethics of Levinas. Journal of Religious Ethics, 40, 427-442. doi:10.1163/156916410X524457

Quine, W. V. (1970). Philosophy of logic. Englewood Cliffs, NJ: Prentice-Hall,

Richardson, W. J. (1995). The irresponsible subject. In A. T. Peperzak, Ed., Ethics as first philosophy (pp. 123-136). New York: Routledge.

Sallis, J. (2010). Levinas and the elemental. In P. Atterton, \& M. Calarco (Eds.), Radicalizing Levinas (pp. 87-94). Albany: State University of New York Press.

Sealey, K. (2010). The primacy of disruption in Levinas's account of transcendence. Research in Phenomenology, 40, 363-377. doi:10.1163/156916410X524457

Tallion, A. (1995). Nonintentional affectivity. In A. T. Peperzak (Ed.), Ethics as first philosophy (pp. 107-122). New York: Routledge.

Thomasson, A. (2007). Ordinary objects. Oxford: Oxford University Press. doi:10.1093/acprof:oso/9780195319910.001.0001

van Inwagen, P. (1990). Material beings. Ithaca and London: Cornell University Press.

Westphal, M. (1995). Levinas's teleological suspension of the religious. In A. T. Peperzak (Ed.), Ethics as first philosophy (pp. 151-160). New York: Routledge.

Wyschogrod, E. (2000). Emmanuel Levinas: The problem of ethical metaphysics. New York: Fordham University Press. 